Kennesaw State University

DigitalCommons@Kennesaw State University

Faculty Publications

$10-1992$

\title{
Industry's Response to Market Liberalization in China: Evidence from Jiangsu Province
}

Penelope B. Prime

Kennesaw State University, pprime@kennesaw.edu

Follow this and additional works at: http:// digitalcommons.kennesaw.edu/facpubs

Part of the Industrial Organization Commons, and the International Economics Commons

\section{Recommended Citation}

Prime, Penelope B. "Industry's Response to Market Liberalization in China: Evidence from Jiangsu Province." Economic Development and Cultural Change 41.1 (1992): pp. 27-50. Print.

This Article is brought to you for free and open access by DigitalCommons@Kennesaw State University. It has been accepted for inclusion in Faculty Publications by an authorized administrator of DigitalCommons@Kennesaw State University. For more information, please contact 


\section{Industry's Response to Market Liberalization in China: Evidence from Jiangsu Province*}

Penelope B. Prime

Kennesaw State College

Introduction

More than a decade has passed since China's communist party endorsed major economic reform at the Third Plenum of the Eleventh Central Committee in December 1978. The reforms have addressed many problems, but efficiency has been the focus of concern. To improve efficiency, China has introduced market mechanisms and reversed its import substitution policies. The purpose of this article is to investigate whether industrial productivity has increased as a result, using Jiangsu Province as a case study.

The background of market liberalization in China is years of development centered on a radical import substitution strategy, which was both international and regional. China is not alone in its reconsideration of import substitution and the role of the market versus the public sector. The oil price increases in the 1970 s resulted in serious debt problems for many developing countries, forcing them to turn to market liberalization and export promotion. The former eastern bloc countries are also in the process of radical domestic and international market reorientation as they restructure their formerly planned systems that had favored import substitution.

Some discussions in the development literature have also been critical of import substitution in favor of outward-looking strategies, ${ }^{1}$ while others argue that markets and export promotion are not a panacea. ${ }^{2}$ In these discussions the example of China is often raised with respect to its particular experience with import substitution followed by an "open door" policy with market liberalization. But while it is clear that reforms have caused radical changes in China's economic system, well beyond what might have been expected to ensue in 1978 , the question remains as to whether economic performance improved during the 1980 s as a result of the reform efforts.

(C) 1992 by The University of Chicago. All rights reserved. 0013-0079/93/4101-0014\$01.00 
In this article I address this question by examining changes in production patterns in industry as a measure of specialization and by estimating industrial productivity as a proxy for efficiency. Studies have suggested that China's regional emphasis of import substitution discouraged production specialization and depressed the growth of inter- and intraprovincial exchange. ${ }^{3}$ In this study I use location quotients to measure changes in interprovincial industrial production patterns to determine whether reforms have resulted in more specialization and, by historical extension, whether a period of "selfreliant" production can be empirically identified. Also, I calculate coefficients of variation for intraprovincial regional production. Production location decisions affect variables such as proximity to supply sources, economies of scale, and concentration of expertise. Further, specialization would be expected to increase as markets became more important in China. Therefore, if specialization increased with market reforms, comparatively higher.industrial productivity would also be expected. This proposition is tested for industry in the second part of the article, using a growth accounting framework. Finally, since some analysts suspect that collective industry is more responsive than state industry to markets in China, I also measure industrial productivity for collective and state industry for the reform period.

Of course, even if both increasing specialization and improved productivity can be shown for the reform period, causation cannot be established since productivity may be affected by numerous variables, including X-efficiency, motivation, and information, as well as specialization. With the time series data that were available for Jiangsu, it was not possible to isolate these factors affecting productivity. ${ }^{4}$ Further, increased specialization could also be due to planning decisions rather than the introduction of market reforms. For the purposes of this article this distinction is not crucial, because if increased specialization is found, and productivity has improved, this will constitute evidence that the reforms are having the intended effects, even if part of the gains are due to better planning. In addition, if planned location decisions have improved it is probably in part because of information gained from market prices.

Unlike other studies that measure industrial productivity in China, this is a provincial level study. National level studies miss the effect of China's regional industrial policies, which may have been at least as important as national policies. When national level studies find that industrial productivity performance was poor during the reform period, they must conclude that reforms are not working or have not gone far enough. Because of the size and economic diversity of China, however, it may be that reforms are having a positive impact in some areas but not others. Examining one province allows for a more isolated test of whether or not reforms have made a difference to China's economy. 
Jiangsu Province is an excellent case for this study for several reasons. First, Jiangsu's relatively industrialized economy serves as a bellwether for the potential success or problems of reform. If marl:et liberalization has not increased specialization or improved industrial performance in Jiangsu, then the prognosis for other parts of China would not be good.

Second, foreign investment in Jiangsu was not large in the $1980 \mathrm{s.}^{5}$ Before 1984 the province had approved only four equity joint ventures, which represented $\$ 2$ million in actual foreign investment. ${ }^{6}$ By 1987 , 71 projects had been approved, but this still represented only $5.1 \%$ of the national total. Therefore, if improved specialization and industrial performance occurred in Jiangsu during the reform period, foreign machinery and techniques could not be the main reason. This would lend support to the explanation that the reforms themselves would have had an effect.

Third, a provincial study provides perspective on studies using national data, which have had mixed results for the reform period. In a World Bank study Gene Tidrick estimated that industrial productivity in state industry decreased between $-1.2 \%$ and $-0.1 \%$ from 1979 to $1983 .{ }^{7}$ Nicholas Lardy's estimates for state industry are comparable. ${ }^{8}$ For the reform period he estimated that productivity fell an average of $-0.3 \%$ annually between 1979 and 1985 . In contrast, a third study by Kuan Chen et al., which adjusted China's official data for state industry to account for pricing and nonproductive investment, estimated that productivity increased between $4.8 \%$ and $5.2 \%$ from 1979 to $1985 .{ }^{9}$

Part of the explanation for these inconsistent results concerns data issues. These are addressed in the Appendix where industrial capital, labor, and output series for Jiangsu are developed. These series take advantage of provincial level data that have become available only recently. Another possible reason for the mixed results in the national level studies is that the productivity estimates are sensitive to how many years of reform the different data sets cover. In this study of Jiangsu the data used extend through 1988 , allowing examination of a decade of reform.

\section{From Import Substitution to Market Liberalization}

Between 1958 and the current reform period, China pursued its own version of import substitution under the influence of Mao Zedong. This version encouraged changes in the structure of production toward "self-reliance" (zili gensheng) for the nation relative to the world economy, and for provinces relative to the national economy. These policies were also carried to the extreme by being imposed even on counties and communes within provinces.

With respect to location decisions, the notion of comparative ad- 
vantage was not accepted in China before the reform period. ${ }^{10}$ Even since the reforms, comparative advantage has found more acceptance with respect to international trade than domestic trade. Nonetheless, some production location decisions did take cost factors into consideration. For example in agriculture, where reforms have allowed households-instead of government officials - to decide what crops to plant, cropping patterns have changed to better suit the growing conditions of particular areas. Also, China now accepts and encourages different rates of development across regions. Policies such as opening coastal cities and regions to foreign investment and trade, as well as targeting these areas for key domestic projects, are part of a new coastal-led development strategy that contrasts sharply with self-reliance. ${ }^{11}$

With the introduction of market liberalizing policies, and official acceptance that regions will develop at different rates, changes in production location would be expected to occur. In agriculture, specialization appears to have led to substantial improvements in yields. ${ }^{12}$ In industry the evidence is less clear. For example, in a study of motor vehicles Thomas Lyons found evidence of continued self-reliant trends. ${ }^{13}$ Reports of protectionism imposed by local officials to help their area's enterprises are common, as are cases of localities processing their own raw materials rather than selling them to other areas with more modern plants. ${ }^{14}$ Hence reliance on other areas for supplies continues to be problematic. Market liberalization, if successful, would be expected to change this behavior, or at least to weaken it.

\section{Jiangsu Province: The Case Study}

Jiangsu is a coastal province in central China. The Yangzi River flows from west to east through southern Jiangsu, entering the Yellow Sea at Shanghai at the southeast edge of the province. Shanghai has been administratively separate from Jiangsu since just after the establishment of the People's Republic, but economic ties between the two have been important. Shanghai, southern Jiangsu, and northern Zhejiang form an economic area that is an engine of growth along the coast, which rivals that of Guangzhou and the special economic zones of the southern part of China.

Historically, Jiangsu's economy was integrated with both international and domestic markets. In 1842 Nanjing, Jiangsu's provincial capital, became a foreign treaty port. The Yangzi River was the main transportation route between Nanjing and Shanghai, also a treaty port. In 1908 a rail line between the two cities was built. For north-south travel the main route was the Grand Canal. Dating originally from the Sui Dynasty (A.D. 589-617), the canal is still functional today. Many smaller canals connect much of Jiangsu's inland areas to these main arteries of transport. Thus Jiangsu's proximity to Shanghai and its transport advantages have meant that the province has historically had 
opportunities for interaction with the international economy as well as substantial trade with China's inland areas. Commercial opportunity made possible the development of cash crops and such nonfarm activities as raising silkworms and handicraft silk and cotton weaving. This specialization caused the lower Yangzi delta in southern Jiangsu to become a net importer of rice as early as the seventeenth century. ${ }^{15}$

Between 1949 and the current reform period, however, the leadership in Jiangsu, as elsewhere in China, had to adhere to China's domestic and international economic policies. Since Jiangsu was relatively industrialized compared with inland provinces, placing development projects in Jiangsu was not a priority for the central government. The First Five-Year Plan (1953-57) emphasized agriculture and water control in the province. Later plans encouraged industrial growth through small scale enterprises and provincially funded projects. Projects in inland provinces received additional funding via the so-called Third Front strategy beginning in the mid-1960s. At this time investment in Jiangsu funded by the central state plan decreased both in absolute terms and as a proportion of total output. ${ }^{16}$

In the reform period, these trends reversed. The central government eased restrictions on foreign trade, increased central investment in the province, and encouraged economic exchange between cities and provinces. Some evidence suggests that Jiangsu benefited greatly from these changes. Industrial output increased rapidly over the last decade so that Jiangsu's production in 1988 surpassed by far all of the other provinces and major municipalities. ${ }^{17} \mathrm{~A}$ major component of the rapid increases in industrial output has been the growth of collective industry. From 1978 to 1988 collective industrial output grew at an average of $20.1 \%$ per year, compared with $10.0 \%$ in state industry. ${ }^{18}$ International trade and domestic commerce have also grown rapidly. Jiangsu's international exports grew at an average of $19.1 \%$ per year in the reform period, compared with $14.0 \%$ from 1952 to $1978 .{ }^{19}$ Domestic retail sales grew at an average of $16.4 \%$ once reforms were begun, compared with only $6.6 \%$ before reform. ${ }^{20}$

In sum, growth in output and trade has been impressive since 1978. The question is whether these developments have been grounded in a more productive economic system, as intended by the proponents of reform.

\section{Measuring Changes in Production Structure: From Self-Reliance to Specialization?}

\section{Interprovincial Specialization}

Rhetorical and anecdotal evidence suggest that China's development under Mao's leadership encouraged self-reliance, and that this approach was abandoned in the reform period after Mao's death. But is there evidence that policies encouraging provincial self-reliance actu- 
ally affected production patterns in provincial economies, which then reversed with reforms? Useful insight into this question can be gained by looking at location quotients for major industrial commodities that compare Jiangsu's output per capita with output per capita for the rest of China in selected years. Specifically, the location quotients are calculated as follows:21

$$
L Q_{i}=\left(Q_{j 1} / L_{1}\right) /\left(Q_{j 2} / L_{2}\right) \gtreqless 1,
$$

where

$L Q_{i}=$ location quotient in year $i$

$Q_{j}=$ gross value of output in industry $j$ (in physical units);

$L=$ population;

$1=$ denotes Jiangsu; and

$2=$ denotes the rest of China (excluding Jiangsu).

If a good has a location quotient of 1 , it means that output per capita in Jiangsu is the same as output per capita for the rest of China. ${ }^{22}$ In this case Jiangsu would not exhibit specialization in the production of that good relative to the rest of China. Quotients greater than 1 would indicate some degree of specialization (the higher the quotient the greater the specialization), while quotients less than 1 would imply that areas other than Jiangsu were specializing in those goods.

For the purpose of this article, however, changes in the quotients over time are of greater interest than the values of the quotients in any particular year. If quotients less than 1 rise while quotients greater than 1 fall, this would indicate a move away from specialization toward self-reliance. Likewise, if quotients less than 1 fall while quotients greater than 1 rise, this would indicate a move toward more specialized production, away from self-reliance. Movements in the location quotients could also reflect relative growth rates generally, so that an increase in all quotients would indicate that industrial output in Jiangsu is growing faster than the national average. Likewise, a decrease in all quotients would indicate that the province is growing more slowly than the national average.

Table 1 presents location quotients for Jiangsu for selected years between 1957 and 1988. Two broad periods are defined by the dates 1957-78, which represent the Maoist period, and 1978-88, which represent the reform period. Table 1 also provides quotients for 1970 and 1983, midpoints for each of the periods.

Looking first at the Maoist period, for the 13 products represented between 1957 and 1970, in the eight cases where the location quotient was less than 1 in 1957, the quotients all increased by 1970; in the five cases where the quotient was equal to or greater than 1 in 1957, the quotients all fell by 1970 . For the entire period, 1957-78, 18 products 
TABLE 1

Location Quotients for Major Industrial Products, Jiangsu Province Compared With China, 1957-88

\begin{tabular}{lccccc}
\hline Products & 1957 & 1970 & 1978 & 1983 & $198 \varepsilon$ \\
\hline Steel & .04 & .13 & .26 & .29 & .43 \\
Pig iron & .01 & .27 & .37 & .37 & .43 \\
Steel products & .01 & .20 & .42 & .55 & .66 \\
Electric power & .55 & .67 & .80 & .87 & 1.08 \\
Coal & .22 & .30 & .44 & .43 & .39 \\
Pesticide & .04 & 1.54 & 1.56 & 3.45 & 4.00 \\
Chemical fertilizer & 5.27 & 1.67 & 1.33 & 1.62 & 1.38 \\
Sulfuric acid & 6.00 & N.A. & 2.50 & 2.13 & 1.70 \\
Small tractors & 0 & 3.18 & 3.21 & 2.24 & 3.00 \\
Motor vehicles & 0 & 1.38 & 1.74 & .93 & 1.00 \\
Engines & 3.00 & N.A. & N.A. & 2.31 & N.A. \\
Cement & 1.90 & 1.00 & 1.13 & 1.37 & 1.37 \\
Plate glass & 0 & .46 & .63 & .85 & .78 \\
Synthetic detergent & 0 & N.A. & .63 & 1.00 & 2.00 \\
Synthetic fiber & 0 & .80 & 1.24 & 1.00 & 5.00 \\
Cloth, blended & 2.31 & 1.74 & 2.26 & 2.34 & 2.71 \\
Silk & 3.30 & N.A. & 2.15 & 3.15 & 4.41 \\
Woolens & .03 & N.A. & 1.32 & 3.53 & 5.23 \\
Paper & 1.00 & .67 & .80 & 1.00 & 1.00 \\
Light bulbs & .34 & N.A. & 1.48 & 1.42 & 1.83 \\
Sewing machines & .20 & .33 & .60 & 1.30 & 1.67 \\
Bicycles & 0 & .06 & .56 & 1.77 & 1.92 \\
Wrist watches & 0 & .75 & 1.85 & 1.91 & .87 \\
Cameras & 0 & N.A. & 1.61 & 3.00 & 2.33 \\
Televisions & 0 & N.A. & 1.00 & 2.67 & 3.40 \\
Radios & N.A. & 2.91 & N.A. & 9.89 \\
Sugar & 5.00 & N.A. & .03 & .04 & .00 \\
Salt & 0 & 1.38 & 2.42 & 1.87 & 1.75 \\
Cigarettes & 1.67 & .60 & .54 & .63 & .48 \\
\hline
\end{tabular}

SOURCEs.-Jiangsu's industrial output: Jiangsu jingji nianjian, 1986 (Jiangsu's economic yearbook) (Nanjing: Jiangsu Renmin Chubanshe, 1986), pp. III:28-30; Jiangsu jingji nianjian, 1984 (Nanjing: Jiangsu Renmin Chubanshe, 1984), pp. 104-6; Jiangsu jingji nianjian. 1989 (Nanjing: Nanjing Daxue Chubanshe, 1989), sec. 3, pp. 42-43. Jiangsu's population: Jiangsu jingji nianjian, 1986, sec. 3, p. 6; Jianguo sanshiwu nianlai de Jiangsu (Jiangsu during the 35 years of China's construction) (Nanjing: Jiangsu Renmin Chubanshe, 1984), p. 43; Jiangsu jingji nianjian, 1989, sec. 3, p. 25. China's industrial output: Zhongguo jingji nianjian, 1986 (China's economic yearbook) (Beijing: Jingji Guanli Zazhi Chubanshe, 1986), pp. 295-97; Zhongguo tongji nianjian, 1989 (China's statistical yearbook) (Beijing: Zhongguo Tongji Chubanshe, 1989), pp. 296-301. China's population: Zhongguo tongii nianjian, 1989, p. 87.

Note. - A zero indicates that the product was not produced in Jiangsu nor elsewhere in China; N.A. indicates that one or more of the variables needed to calculate the location quotient were not available.

are represented. Again the quotients rose for every product with a starting quotient of less than 1 , and fell for every product with a starting quotient of 1 or higher.

In other words, every product exhibited a change in production consistent with a movement toward a location quotient of 1 , which can be interpreted as less specialization and greater self-reliance. Fur- 
ther, since low quotients rose in combination with high quotients falling, these movements indicate changes in provincial production specialization, not a difference in regional growth rates. Therefore these results suggest that the self-reliance policies of the Maoist period did in fact have an effect on production patterns in Jiangsu.

Did production patterns change with reforms? For production to become more specialized, as reforms intended, quotients with values less than 1 in 1978 should decrease, while quotients greater than 1 should increase. First, comparing 1978 with 1983, there are 27 industrial products represented. Of the 12 that had quotients less than 1,10 increased while only one decreased (and one remained the same). Of the 15 that had quotients greater than 1 , nine increased and six decreased. Therefore, out of the 27 , only 10 moved in the direction of more specialized production. Comparing 1978 with 1988 , however, out of 28 products, 14 quotients moved in the direction of more specialization. Of the quotients that were less than 1 in 1978, nine increased and three decreased, and of the quotients that were greater than or equal to 1 , five decreased while 11 increased.

In sum, during the reform period the pattern of change in the quotients is clearly different than during the Maoist period. By 1988, half of the products represented moved in the direction of more specialized production in Jiangsu relative to the rest of China. This contrasts sharply with the fact that none of the products moved toward specialization between 1957 and 1978.

However, 20 out of 28 quotients increased during the reform period, which also indicates that for many of the industrial products represented in table 1 per capita production in Jiangsu was growing faster than the national average. These trends imply that China's policy of developing the coastal areas has been effective. If data for southern Jiangsu were combined with northern Zhejiang and Shanghai, or even if northern Jiangsu was separated from southern Jiangsu, these regional specialization trends would probably be much more pronounced.

Jiangsu's production patterns show that policies encouraging selfreliance, and later market reform, indeed had an effect on the economy. Since these policies were extended to cities and counties, the next section examines evidence on production patterns within the province.

\section{Intraprovincial Specialization}

Information on degrees of specialization within provinces is difficult to find, but a preliminary investigation of the reform period is possible by looking at dispersion of industrial production over the province's 11 administrative regions. ${ }^{23}$

Dispersion of Jiangsu's production structure is measured by coef- 
TABLE 2

Coefficients of Variation of Industrial OUtPut AMONG JIANGSU's 11 RegIONS, 1978-88

\begin{tabular}{lcccc}
\hline & 1978 & 1980 & 1985 & 1988 \\
\hline Gross value of industrial output, new definition & .53 & .54 & .60 & .64 \\
Gross value of industrial output, old definition & .54 & .54 & .56 & .60 \\
\hline
\end{tabular}

SOURCES.-Jiangsu jingji nianjian, 1984 (Jiangsu's economic yearbook) (Nanjing: Jiangsu Renmin Chubanshe, 1984), p. 44; Jiangsu jingji nianjian, 1986 (Nanjing: Jiangsu Renmin Chubanshe, 1986), sec. 3, pp. 18, 27; Jiangsu tongji nianjian, 1988 (Jiangsu's statistical yearbook) (Nanjing: Zhongguo Tongji Chubanshe, 1989), p. 191; Jiangsu jingji nianjian, 1989 (Nanjing: Nanjing Daxue Chubanshe, 1989), sec. 3, pp. 26, 29, 39-41.

Note.-The difference between the new and the old definition is the inclusion of village industrial enterprises in agricultural output in the old definition and in industrial output in the new definition.

ficients of variation given in table 2 . These coefficients cover the province's 11 administrative regions for available years during the reform period for industry. ${ }^{24}$ If more specialized production has occurred between regions within the province, the coefficient is expected to increase. Beginning in 1984, village industry was counted as industrial output (new definition); before this it was part of agricultural output (old definition). ${ }^{25}$

With the new definition, the dispersion of industrial production throughout the province increased after 1978, which is consistent with more specialized production. The coefficient of variation was .53 in 1978 , increasing to .64 by $1988 .^{26}$ Since specialization may have occurred within industry as well, these coefficients give a minimum measure of increased specialization. Also, the coefficient could have increased because industrial output was growing faster in some regions than in others. This still would suggest that the reforms had an effect, since in the period before the reforms the policies of self-reliance included discouraging some areas from growing faster than others.

Using the old definition, excluding village industry, the coefficient increased, but only from .54 to $.60 .{ }^{27}$ The smaller change in the coefficient with the old definition suggests that geographical specialization has been important in village industry. This result is consistent with the general impression that small, collective enterprises are more responsive to market pressures than are state enterprises.

\section{Measuring Industrial Productivity}

\section{Total Industrial Productivity}

This section tests the proposition that because production patterns in the reform period were more specialized than those of the Maoist period, industrial productivity is expected to have improved in the reform period compared with earlier years. To do this, consistent data 
spanning both the reform period and the years before 1978 are needed. This is not a simple problem. Drawing on numerous sources it is possible to piece together a reasonable total industrial productivity estimate over time for Jiangsu, as well as estimates for state and collective industry from 1980 to 1988 , even though many data problems remain. The Appendix describes the compilation of these series, the problems involved, and the sources utilized.

To measure changes in Jiangsu's industrial productivity, I use a growth accounting framework. ${ }^{28}$ The production function is assumed to be Cobb-Douglas with the form: ${ }^{29}$

$$
Q(t)=A(t) K(t)^{b} L(t)^{1-b},
$$

where

$$
\begin{aligned}
Q(t) & =\text { industrial output; } \\
L(t) & =\text { industrial labor; } \\
K(t) & =\text { fixed industrial assets; } \\
b & =\text { elasticity of output with respect to capital; } \\
(1-b) & =\text { elasticity of output with respect to labor; } \\
A(t) & =\text { contributions to output from factors other than } \\
& \text { capital and labor inputs; and } \\
t= & \text { time. }
\end{aligned}
$$

Taking natural logs results in

$$
\ln Q(t)=\ln A(t)+b \ln K(t)+(1-b) \ln L(t) .
$$

Finally, differentiating with respect to time results in the following:

$$
q(t)=a(t)+b k(t)+(1-b) l(t),
$$

where $q(t)=$ the growth rate of output; $k(t)=$ the growth rate of capital; $l(t)=$ the growth rate of labor; and $a(t)=$ growth in total factor productivity.

This equation can be rewritten as

$$
a(t)=q-[b k+(1-b) l] .
$$

With this approach, $a(t)$ is referred to as the "residual" and is interpreted as that part of growth that is not explained by growth in capital and labor. Therefore, increases in $a(t)$ are attributed to productivity growth. The size of the residual will be influenced by a number of factors including technological progress, the quality of the work 
force, and changes in capacity utilization, but data restrictions preclude the separation of these factors. Since the purpose here is to test whether productivity generally has been influenced by China's economic policies, it is sufficient to measure $a(t)$ and compare its average growth in different time periods.

Finally, estimates for the elasticities are needed. Using equation (3) and the data in table Al in the Appendix, I estimated the capitaloutput elasticity for industry in Jiangsu to be .736 , and the labor-output elasticity to be .264 . This capital-output parameter is high compared with estimates for China. Chen et al. estimated that the state industrial capital-output elasticity for China was .542 for capital and .458 for labor, using their revised data. While the Chen et al. study was concerned with state industry, in another study Gary Jefferson estimated elasticity parameters based on 1985 cross-sectional data for state and collective industry. ${ }^{30}$ For the state sector he found a capital-output elasticity of .309 and a labor-output elasticity of .691 , and for the collective sector he found a capital-output elasticity of .722 and a laboroutput elasticity of $.278 .{ }^{31}$ Since the total industrial productivity estimates for Jiangsu include state and collective industry, and since by the mid-1980s collective industry produced over half of total industrial output in Jiangsu, it is plausible that the capital-output elasticity is higher than that for state industry measured at the national level.

The total industrial productivity results are given in table 3 . The table shows average annual growth rates for output and the weighted inputs, with $a(t) 1$ as the difference between these two. The residual was negative, $-1.7 \%$ on average, during the First Five-Year Plan (1953-57), and $-8.4 \%$ from 1958 to 1965 . During the cultural revolution period (1966-75), productivity increased an average of $5.1 \%$ per year in the first half and $0.2 \%$ in the second half.

These results differ to some extent from the studies on China's industrial productivity cited in the introduction. These studies generally report positive productivity during the First Five-Year Plan, with very low or negative productivity from 1957 to 1978 . The low productivity results in the 1950s in Jiangsu may be due to the fact that the state plan did not favor industry in Jiangsu. These results may also be due to the figures used for Jiangsu's capital stock in the 1950s (see notes to table $A 1$ in the Appendix).

For the reform period, table 3 shows that productivity decreased $-0.4 \%$ between 1976 and 1980 , but then increased $5.3 \%$ per year between 1981 and 1985, and 3.3\% between 1986 and 1988 .

To see whether productivity growth was higher during the reform period compared with the Maoist period, the last two rows in table 3 compare average annual productivity growth between the two periods. From 1953 to 1978, productivity fell an average of $2.1 \%$ annually, while from 1979 to 1988 productivity increased an average of $4.4 \%$ annually. 
TABLE 3

Total Industrial. Factor Productivity, Jiangsu Province, 1953-88 (Average Annual Growth Rates)

\begin{tabular}{lccr}
\hline & Output & $.736 k+.264 l$ & $a(t) 1$ \\
\hline $1953-57$ & 10.0 & 11.7 & -1.7 \\
$1958-65$ & 9.5 & 17.9 & -8.4 \\
$1966-70$ & 11.6 & 6.5 & 5.1 \\
$1971-75$ & 11.4 & 11.2 & .2 \\
$1976-80$ & 13.4 & 13.8 & -.4 \\
$1981-85$ & 14.0 & 8.7 & 5.3 \\
$1986-88$ & 17.3 & 14.0 & 3.3 \\
$1953-78$ & 10.7 & 12.8 & -2.1 \\
$1979-88$ & 15.4 & 11.0 & 4.4 \\
\hline
\end{tabular}

Note.-Growth rates are continuous and are based on indexes given in table A2. See text for definition of variables.

These results support the proposition that reforms have had a positive effect on productivity.

Since this result may be sensitive to the tentative figures for capital and labor in the 1950s, productivity growth was reestimated leaving these figures out. It did not change the final conclusion. Productivity change for $1965-78$ was $1.9 \%$ on average per year, compared with $5.2 \%$ for $1979-88 .{ }^{32}$ While the productivity estimates for both periods were higher than when the 1950 s were included, it was still the case that productivity was higher in the reform period. The result that productivity growth increased with reforms may also be sensitive to the elasticity parameters. To check this, I applied the Chen et al. parameters derived from national state industry to the Jiangsu data (i.e., with a capital-output parameter of .542) as a comparison. This procedure also did not change the conclusion. Productivity decreased $-1.3 \%$ per year between 1953 and 1978, and increased 4.7\% between 1979 and 1988. If the 1950s are excluded, using the Chen et al. parameters, productivity increased $2.0 \%$ per year between 1965 and 1978, but increased $6.1 \%$ between 1979 and 1988 . Therefore, the conclusion that productivity growth was higher during the reform period compared with the earlier period was not affected by any of these adjustments.

Finally, to see how sensitive the results were to the revisions of the capital stock, which adjusted the value of capital for inflation between 1980 and 1988, I reestimated productivity using unrevised capital data (col. 2, tables A1 and A2). In this case productivity decreased $-1.8 \%$ in the years before reform, and increased $0.2 \%$ during reform. ${ }^{33}$ Therefore, even with unrevised capital data, productivity increased with reform, although this case was by far the weakest. This result is consistent with the Chen et al. study, which found increasing productivity during reform using revised data, in contrast to other studies, 
which found poorer productivity performance using unrevised data. However, the argument for adjusting these data is strong because when they are not adjusted capital growth is unrealistically high. Further, the revisions used here in the case of Jiangsu were conservative. Because of data restrictions, I did not take out housing investment, although other studies suggest that this component of investment increased the fastest during the reform period (see Appendix). If housing had been taken out, it is likely that the estimates of productivity performance would have been even higher for the reform period.

\section{State and Collective Industrial Productivity}

The productivity results discussed so far are based on total industrial output, including both state and collective industry. However, the higher than average industrial growth in Jiangsu during the reform period was largely due to relatively faster growth in collective industry compared with state industry. In order to understand further what effects the reforms have had on productivity, it is helpful to examine whether the collective sector exhibited higher growth in productivity when compared with the state sector. In these estimates, capital was adjusted for both inflation and housing.

Tables 4 and 5 measure total factor productivity for state and for collective industry in the province. Since the few data points available for Jiangsu's state and collective industry made direct estimates of these elasticities questionable, I used Jefferson's parameter estimates (i.e., capital-output elasticity of .309 for state industry, and .722 for collective industry). In the data series for Jiangsu's state and collective industry, both gross and net output were available and were utilized.

First using gross output, productivity in state industry in the province increased $4.1 \%$ per year on average between 1981 and 1988 . In

\section{TABLE 4}

Total Factor Productivity for State Industry, Jiangsu Province, 1981-88 (Average Annual Growth Rates)

\begin{tabular}{lccccr}
\hline & $\begin{array}{c}\text { Output, } \\
\text { Gross }\end{array}$ & $\begin{array}{c}\text { Output, } \\
\text { Net }\end{array}$ & $\begin{array}{c}\text { Inputs, } \\
.309 k+.691 l\end{array}$ & $\begin{array}{c}a(t) 2 \\
\text { (Gross) }\end{array}$ & $\begin{array}{r}a(t) 3 \\
(\mathrm{Net})\end{array}$ \\
\hline 1981 & 4.6 & 3.6 & 2.5 & -2.1 & 1.1 \\
1982 & 7.5 & 3.5 & 7.5 & .0 & -4.0 \\
1983 & 9.8 & 6.6 & 4.1 & 5.7 & 2.5 \\
1984 & 7.7 & 12.9 & 1.9 & 5.8 & 11.0 \\
1985 & 13.5 & 12.0 & 5.4 & 8.1 & 6.6 \\
1986 & 9.7 & 4.3 & 6.2 & 3.5 & -1.9 \\
1987 & 12.7 & 8.1 & 10.5 & 2.2 & -2.4 \\
1988 & 11.4 & 11.5 & 6.1 & 5.3 & 5.4 \\
Average & 9.6 & 7.8 & 5.5 & 4.1 & 2.3 \\
\hline
\end{tabular}

NotE.-Growth rates are continuous and are based on indexes given in table A5. See text for definition of variables. 
TABLE 5

Total Factor Productivity for Collective Industry, Jiangsu Province, 1981-88 (Average Annual Growth Rates)

\begin{tabular}{lccccr}
\hline & $\begin{array}{c}\text { Output, } \\
\text { Gross }\end{array}$ & $\begin{array}{c}\text { Output, } \\
\text { Net }\end{array}$ & $\begin{array}{c}\text { Inputs, } \\
.722 k+.278 t\end{array}$ & $\begin{array}{c}a(t) 4 \\
(\text { Gross) }\end{array}$ & $\begin{array}{r}a(t) 5 \\
(\text { Net) }\end{array}$ \\
\hline 1981 & 11.0 & 7.6 & 12.5 & -1.5 & -4.9 \\
1982 & 8.4 & 5.8 & 12.0 & -3.6 & -6.2 \\
1983 & 15.2 & 13.9 & 7.6 & 7.6 & 6.3 \\
1984 & 29.5 & 22.3 & 8.9 & 20.6 & 13.4 \\
1985 & 31.1 & 30.1 & 19.5 & 11.6 & 10.6 \\
1986 & 18.5 & 8.7 & 17.5 & 10.0 & -8.8 \\
1987 & 22.7 & 15.2 & 17.2 & 5.5 & -2.0 \\
1988 & 23.4 & 20.1 & 14.8 & 8.6 & 5.3 \\
Average & 20.0 & 15.5 & 13.8 & 6.2 & 1.7 \\
\hline
\end{tabular}

NoTE.-Growth rates are continuous and are based on indexes given in table AS. See text for definition of variables.

collective industry, productivity increased $6.2 \%$ per year over the same period. These results suggest that reforms have had a positive effect on both sectors but that collective industry performed better.

However, if net output is used the results reverse. In this case productivity increases $2.3 \%$ in state industry, but only $1.7 \%$ in collective industry. One explanation of this discrepancy may be intermediate inputs. Ideally, intermediate inputs should be included in the production function when gross output is used. If they are not included, part of the productivity estimate is capturing increases in these inputs. If intermediate inputs increased faster in collective enterprises than in state enterprises during the reform period, as one study by Jefferson et al. shows, then performance in state industry would be expected to be better when net output is used. ${ }^{34}$ Further, the indices in table A4 show that in Jiangsu both capital and labor increased substantially faster in collective industry than in state industry.

In sum, then, the results comparing productivity change between state and collective industry in Jiangsu are inconclusive. However, they do suggest caution in interpreting the fast growth in collective industrial output as evidence that reforms have made China's economy more efficient.

\section{Conclusion}

Efficient production has historically not been the hallmark of import substitution or planned economies. China's concern about efficiency led its leadership to liberalize markets and to reverse its international and regional import substitution policies. The results presented in this article contribute evidence that these reforms have indeed improved economic performance as measured by production specialization and 
productivity in industry. These results held under various parameter assumptions.

In this study, productivity performance in Jiangsu Province during the reform period was shown to be substantially more positive than in some of the productivity estimates done for China nationally. This suggests the possibility that the effects of the reforms are not uniform across regions. This nonuniformity would not be captured in a national study. Another possible explanation for the difference in results is the methods used to adjust the data for pricing and aggregation problems, and the number of years of reform covered. These issues are also addressed in this article.

The productivity results comparing collective and state industry in Jiangsu were less definitive. Using gross value of industrial output, productivity growth in collective industry was higher than in state industry, but this result was reversed when net output was used. This suggests that future research on total factor productivity needs to include intermediate inputs.

Finally, I found some evidence that Jiangsu's production patterns had become more specialized with reforms and that the province has been growing faster than the national average. There was also a surprisingly strong indication that production patterns during the Maoist period did respond to regional import substitution, or "self-reliant," policies. Much work on China assumes that these policies had an effect, but few attempt to show it.

The case of Jiangsu has shown that China's reform policies have not only been a major turnaround in content and intent but have also had substantial positive effects on economic performance. Whether other areas have had results similar to those of Jiangsu remains to be explored.

\section{Appendix}

Data

Total Provincial Industry, 1952-88 (See Table AI)

Output. Gross value of total industrial output in 1980 (comparable) prices (col. 1, table A1), using the definition of industry that excludes industrial output of village (cun ji cun yixia gongye) enterprises.

Ideally this series would use net industrial output (e.g., guomin shouru) in constant prices. Data on total net industrial output were available in current prices, but a consistent price deflator for 1952-88 with 1980 as the base year was not. Output in 1980 comparable prices, due to the way groups of years with similar base-year prices are linked together, has some upward bias over time compared with using an earlier price base, but it is much less than would be the case with nondeflated, current prices. ${ }^{35}$

A second problem is that net industrial output was available for all years for Jiangsu using the new definition, that is, including industrial output from 
village enterprises, but the capital and labor data excluded village industry and thus were compatible with the old definition.

Capital. Total net fixed industrial assets, excluding village industry. The capital series (original data; col. 2, table A1) is total net fixed capital for 1952-75, and total net fixed capital for independent accounting units for 1978 and after. Using capital of independent accounting units, rather than capital of all industrial enterprises, resulted in underestimating capital but apparently not too seriously. This is supported by data from 1980, the only year that the two series overlap. In that year, industrial capital stock (in original value) for independent accounting units was 19,501 million; for total industrial enterprises it was 19,541..$^{36}$ Furthermore, independent accounting units produced over $96 \%$ of total output in Jiangsu, and it is likely that the excluded production units were relatively labor intensive. The more important deficiencies with these figures are that they include the value of nonproductive investment such as housing and that they are in current prices. ${ }^{37}$

For Jiangsu, 1978 is the first year for which there exists published data on housing investment as a separate category within industrial investment. For the whole period 1952-88, the proportion of nonproductive investment, including housing, was available for total capital construction investment in state enterprises but not for total industrial enterprises or even state industrial enterprises. Nonproductive investment includes more than just investment in housing (and not all of it should be considered "nonproductive"). Nonproductive investment is also higher in the figures for total state capital construction investment as compared with the figures for industry alone. For these reasons, applying this proportion to industrial investment would result in an underestimation of capital. Also, since housing investment increased rapidly during the reform period, taking it out would underestimate the growth in capital stock and therefore overestimate productivity increases, biasing the results in favor of the hypothesis that reforms have resulted in better productivity performance. For these reasons the capital series in table Al were not adjusted for housing investment.

With respect to pricing, deflators for state and collective capital for the reform period have been constructed by Jefferson et al., but a deflator for 1952-88 with 1980 as the base year has not. ${ }^{38}$ Deflators constructed in 1952 prices for components of capital show that inflation had a large impact on capital in the 1980s but that before the reform period capital prices were less affected and in some years they even decreased. ${ }^{39}$ Therefore I have deflated the original capital figures for Jiangsu beginning in 1980, but not before, which resulted in the revised figures (col. 3, table A1). To deflate total industrial capital stock, I first applied the proportion of state industrial output to total industrial output in the province to the capital stock figures as an approximation of the proportion of capital in state industry. Then I deflated the proportion, using the Jefferson et al. price deflator for state capital for China. Assuming the remaining proportion of capital approximated collective capital, I deflated it using the Jefferson et al. defiator for collective industrial capital for China. Finally I added the two deflated parts.

Labor. Total industrial labor, excluding village industrial labor. The la. bor figures (col. 4, table A1) for 1962-83 were derived by combining figures for output per worker with total output figures. The figure for 1957 came from 
summing state and urban collective industrial labor forces. Labor in 1952 was derived by assuming that the rate of increase of total industrial labor equals that of state industry, working backward from 1957. The figures for 1984 and 1985 came from the industrial census; the figures for 1986 and 1987 are from Jiangsu's 1988 statistical yearbook; and the 1988 figure was derived from employment figures given in Jiangsu's 1989 economic yearbook. It should be noted that the figure for 1977 seems too high, but this does not affect the productivity estimates as this year is excluded. Also, the census gave 4.4 million industrial workers for 1980 , compared with 4.8 in this series.

\section{State and Collective Industry, 1980-88 (See Tables A3 and A4)}

The separate data for state and collective industry for independent accounting units for 1980-88 are more consistent than those for total industry. Output is given in both net and gross terms. Gross output (col. 2, table A3) is in 1980 prices, and net output, reported in current prices (col. 1, table A3) is deflated (col. 1, table A4) using the Jefferson et al. deflators for state and collective net output for China. Both gross and net output in this series use the definition of industry that excludes village industry and, therefore, is consistent with the capital and labor figures. Capital (col. 3, table A3) is net value of fixed capital reported in current prices, which is deflated (col. 3, table A4) using the same price series for state and collective capital as in the series on total industrial capital. Employment (col. 4, table A3) for state industrial enterprises is the total state industrial labor force, since labor figures for only independent accounting units is not available. Employment figures for collectives, including urban collectives and rural township industrial enterprises but excluding industry in villages, are more scarce. Figures for 1980,1982 , and 1985-88 are available. The figures for the remaining 3 years are interpolated from these available figures. 
TABLE Al

Total Industrial Output, Capital, and Labor Series, Jiangsu Province, 1952-88 (Millions)

\begin{tabular}{lcccc}
\hline & $\begin{array}{c}\text { Output, } \\
\text { Gross } \\
(1)\end{array}$ & $\begin{array}{c}\text { Capital, } \\
\text { Original } \\
(2)\end{array}$ & $\begin{array}{c}\text { Capital, } \\
\text { Revised } \\
(3)\end{array}$ & $\begin{array}{c}\text { Labor } \\
(4)\end{array}$ \\
\hline 1952 & 1,965 & $289^{*}$ & 289 & .520 \\
1957 & 3,261 & $536^{*}$ & 536 & .860 \\
1962 & 4,097 & 2,225 & 2,225 & 1.024 \\
1965 & 6,931 & 2,738 & 2,738 & 1.150 \\
1970 & 12,486 & 3,730 & 3,730 & 1.918 \\
1975 & 22,053 & 6,490 & 6,490 & 3.615 \\
1976 & 23,918 & N.A. & N.A. & 3.519 \\
1977 & 28,211 & N.A. & N.A. & 4.343 \\
1978 & 32,017 & 10,310 & 10,310 & 3.885 \\
1979 & 36,345 & 11,730 & 11,730 & 4.298 \\
1980 & 43,119 & 13,402 & 13,402 & 4.832 \\
1981 & 46,569 & 15,633 & 14,822 & 5.164 \\
1982 & 50,321 & 17,875 & 16,843 & 5.355 \\
1983 & 56,945 & 19,973 & 17,510 & 5.636 \\
1984 & 68,004 & 22,019 & 18,088 & 5.763 \\
1985 & 86,390 & 27,200 & 20,896 & 6.485 \\
1986 & 98,326 & 33,241 & 23,808 & 6.824 \\
1987 & 119,323 & 42,229 & 28,594 & 7.200 \\
1988 & 145,771 & 50,478 & 32,320 & 7.432 \\
\hline
\end{tabular}

Sources.-Output: 1952-87: Jiangsu tongji nianjian, 1988 (Jiangsu's statistical yearbook) (Nanjing: Zhongguo Tongji Chubanshe, 1988), pp. 186-87; 1988: Jiangsu jingji nianjian, 1989 (Jiangsu's economic yearbook) (Nanjing: Nanjing Daxue Chubanshe, 1989), pp. 39, 41. Capital: 1952-75: Jiangsu Statistical Bureau, see Penelope B. Prime, "The Impact of Self-Sufficiency on Regional Industrial Growth and Productivity in Post-1949 China: The Case of Jiangsu Province"' (Ph.D. diss., University of Michigan, 1987), table 4.17, pp. 111-12; 1978-87: Jiangsu tongji nianjian, 1988, pp. 210-11; 1988: Jiangsu jingji nianjian, 1989, sec. 3, p. 44. Deflators: Gary Jefferson, Thomas G. Rawski, and Yuzin Zheng, "Growth, Efficiency and Convergence in China's State and Collective Industry," Economic Development and Cultural Change 40 (1992): 239-66. Labor: Jiangsu Statistical Bureau, see Prime, "The Impact of Self-Sufficiency on Regional Industrial Growth and Productivity in Post-1949 China," table B.4, p. 187, for net output in 1980 prices, 1952-82; Jiangsu jingji nianjian, 1984 (Nanjing: Jiangsu Renmin Chubanshe, 1984), p. 26, for net output in constant prices, 1983; Jianguo sanshiwu nianlai de Jiangsu (Jiangsu during the 35 years of China's construction) (Nanjing: Jiangsu Renmin Chubanshe, 1984), p. 24, for net industrial output per worker, 1962-83; Guowu Yuan Quanguo Gongye Pucha Lingdao Xiaozu Bangongshi, ed., Zhonghua Renmin Gonghe Guo 1985 nian gongye pucha ziliao (China's 1985 general industrial survey) (Beijing: Zhongguo Tongji Chubanshe, 1988), p. 124, for the 1984 and 1985 figures; Jiangsu tongji nianjian, 1988 , pp. 94 and 125, for the 1986 and 1987 figures; and the 1988 figure was calculated from Jiangsu jingji nianjian, 1989, pp. III-28, 48, 54.

Note.-Column headings are defined as follows. Output = total gross value of industrial output, 1980 comparable prices, old definition. Beginning in 1980, gross value of industrial output figures include industrial output from "individual" (geti) enterprises. Capital, original = year-end, net value of fixed assets in industry, current prices. The net figures for 1962-75 were derived from figures provided by the Jiangsu Statistical Bureau in original value and then reduced to net value using the ratio of net to gross for the corresponding years for national fixed assets figures. Figures for 1949-75 are for total industry; the 1978 figure is derived from fixed assets for total industrial independent accounting units in original value, reduced to net value using $.72 ; 1980,1984-87$ figures are total net fixed assets for industrial independent accounting units; 1981-83 figures are 
estimated using the annual percentage increase in net fixed assets for state plus collestive independent accounting units. Capital, revised $=$ the original capital figures in col. 2 revised by deflating them for the period 1980-1988. Labor = total industrial labor force, excluding village industrial labor. The 1962-83 figures were derived by combining net industrial output in 1980 prices with net industrial output per worker in 1980 prices. The figure for 1957 is the sum of state and urban collective industrial labor forces, and the figure for 1952 is derived by assuming the rate of increase of total industrial labor to be equal to that of state industry, working backward from 1957. Figures for state industrial labor force were provided by the Jiangsu Statistical Bureau. The figures for 1984 and 1985 are from China's 1985 industrial census; the figures for 1986 and 1987 were published in Jiangsu's 1988 statistical yearbook; and the 1988 figure was derived from figures published in Jiangsu's 1989 economic yearbook. N.A. = not available.

* The capital figures for 1952 and 1957 were calculated by working backward from the 1962 figure using the increase in original value of capital in state industry and then deflating these to their net values using the 1957 deflator of .71 . For the 1952 figure, it was further assumed that state assets represented $12 \%$ of Jiangsu's total industrial assets at original value, the rest being primarily private. The $12 \%$ is based on state and private asset figures for the city of Wuxi. Between 1953 and 1957, the increase in assets was almost entirely accounted for by the state sector, since cooperative and private enterprises were nationalized.

TABLE A2

Indexes for Total Industrial OUtput, Capital, and Labor, Jiangsu Province, 1952-88

\begin{tabular}{lcccc}
\hline & $\begin{array}{c}\text { Output, } \\
\text { Gross } \\
(1)\end{array}$ & $\begin{array}{c}\text { Capital, } \\
\text { Original } \\
(2)\end{array}$ & $\begin{array}{c}\text { Capital, } \\
\text { Revised } \\
(3)\end{array}$ & $\begin{array}{c}\text { Labor } \\
(4)\end{array}$ \\
\hline 1952 & 100 & 100 & 100 & 100 \\
1957 & 166 & 185 & 185 & 165 \\
1962 & 208 & 770 & 770 & 197 \\
1965 & 353 & 947 & 947 & 221 \\
1970 & 635 & 1,291 & 1,291 & 369 \\
1975 & 1,122 & 2,246 & 2,246 & 695 \\
1978 & 1,629 & 3,567 & 3,567 & 747 \\
1979 & 1,850 & 4,059 & 4,059 & 827 \\
1980 & 2,194 & 4,637 & 4,637 & 929 \\
1981 & 2,370 & 5,409 & 5,129 & 993 \\
1982 & 2,561 & 6,185 & 5,828 & 1,030 \\
1983 & 2,898 & 6,911 & 6,059 & 1,084 \\
1984 & 3,461 & 7,619 & 6,259 & 1,108 \\
1985 & 4,396 & 9,412 & 7,230 & 1,247 \\
1986 & 5,004 & 11,502 & 8,238 & 1,312 \\
1987 & 6,072 & 14,612 & 9,894 & 1,385 \\
1988 & 7,418 & 17,466 & 11,183 & 1,429 \\
\hline
\end{tabular}

Source. - Table A1. 
TABLE A3

State and Collective Industrial Output, Capital, and Labor Series, Independent Accounting Units, Jiangsu Province, 1980-88 (Millions)

\begin{tabular}{lcccc}
\hline & $\begin{array}{c}\text { Net Output } \\
(1)\end{array}$ & $\begin{array}{c}\text { Gross Output } \\
(2)\end{array}$ & $\begin{array}{c}\text { Capital } \\
(3)\end{array}$ & $\begin{array}{c}\text { Labor* } \\
(4)\end{array}$ \\
\hline State industry: & & & & \\
1980 & 7,193 & 26,254 & 9,577 & 1.8916 \\
1981 & 7,485 & 27,486 & 10,992 & 1.9928 \\
1982 & 7,757 & 29,631 & 12,414 & 2.0688 \\
1983 & 8,285 & 32,679 & 13,693 & 2.1257 \\
1984 & 9,613 & 35,284 & 14,576 & 2.1297 \\
1985 & 11,531 & 40,399 & 17,162 & 2.2178 \\
1986 & 12,436 & 44,506 & 20,042 & 2.3000 \\
1987 & 14,428 & 50,528 & 24,991 & 2.3882 \\
1988 & 17,338 & 56,641 & 28,672 & 2.4947 \\
Collective industry: & & & & \\
1980 & 4,929 & 15,552 & 3,762 & 2.8874 \\
1981 & 5,316 & 17,359 & 4,571 & $3.0720 \dagger$ \\
1982 & 5,579 & 18,873 & 5,287 & 3.2658 \\
1983 & 6,382 & 21,988 & 6,078 & $3.5480 \dagger$ \\
1984 & 8,032 & 29,513 & 7,092 & $3.8550 \dagger$ \\
1985 & 11,325 & 40,303 & 9,557 & 4.1884 \\
1986 & 12,540 & 48,473 & 12,553 & 4.4374 \\
1987 & 15,137 & 60,805 & 16,169 & 4.7019 \\
1988 & 19,288 & 76,875 & 20,198 & 4.9375 \\
\hline
\end{tabular}

SourCes.-Output, state and collective, gross value of industrial output in 1980 prices and net value of industrial output in current prices, for independent accounting units: Jiangsu jingii nianjian, 1986 (Jiangsu's economic yearbook) (Nanjing: Jiangsu Renmin Chubanshe, 1986), sec. 3, pp. 32-33, for 1978-84; Jiangsu tongii nianjian, 1988 (Jiangsu's statistical yearbook) (Nanjing: Zhongguo Tongii Chubanshe, 1988), pp. 212-15, for 1985-87; Jiangsu jingii nianjian, 1989, sec. 3, pp. 45-46 for 1988. Capital, state and collective: net value of fixed capital, current prices, for independent accounting units, Jiangsu jingji nianjian, 1986, sec. 3, pp. 32-33, for 1978-85; Jiangsu tongii nianjian, 1988, pp. 212-15, for 1986 and 1987; Jiangsu jingi nianjian, 1989, sec. 3, pp. 45-46, for 1988. Labor, total state industrial Jabor: Jiangsu tongii nianjian, 1988, p. 106; collective: Jiangsu Statistical Bureau (see Penelope B. Prime, "The Impact of Self-Sufficiency on Regional Industrial Growth and Productivity in Post-1949 China: The Case of Jiangsu Province" [Ph.D. diss., University of Michigan, 1987], table 4.16, p. 109, the sum of urban and commune industrial labor from cols. 4 and 5), for 1980 and 1982; Jiangsu tongji nianjian, 1988, p. 125, for 1985-87.

* The state labor figures are total state industrial labor force, which will be slightly higher than the state industrial labor force for independent accounting units.

$\uparrow$ These figures are derived by interpolation. 
TABLE A4

State and Collective Industrial Output, Capital, and Labor Series, Independent Accounting Units, Jiangsu Province, 1980-88,

ADJUSTED FOR INFLATION AND HOUSING INVESTMENT (Millions)

\begin{tabular}{lcccc}
\hline & $\begin{array}{c}\text { Net Output } \\
(1)\end{array}$ & $\begin{array}{c}\text { Gross Output } \\
(2)\end{array}$ & $\begin{array}{c}\text { Capital } \\
(3)\end{array}$ & $\begin{array}{c}\text { Labor } \\
(4)\end{array}$ \\
\hline $\begin{array}{l}\text { State industry: } \\
1980\end{array}$ & & & & \\
1981 & 7,193 & 26,254 & 7,604 & 1.8916 \\
1982 & 7,455 & 27,486 & 7,303 & 1.9928 \\
1983 & 7,718 & 29,631 & 8,607 & 2.0638 \\
1984 & 8,244 & 32,679 & 9,209 & 2.1257 \\
1985 & 9,379 & 35,284 & 9,742 & 2.1297 \\
1986 & 10,579 & 40,399 & 10,542 & 2.2178 \\
1987 & 11,044 & 44,506 & 11,735 & 2.30100 \\
1988 & 11,973 & 50,528 & 14,531 & 2.38832 \\
Collective industry: & 13,440 & 56,641 & 15,858 & 2.4947 \\
1980 & & & & \\
1981 & 4,929 & 15,552 & 3,762 & 2.8874 \\
1982 & 5,316 & 17,359 & 4,362 & 3.0720 \\
1983 & 5,635 & 18,873 & 5,016 & 3.2658 \\
1984 & 6,473 & 21,988 & 5,398 & 3.54830 \\
1985 & 8,089 & 29,513 & 5,915 & 3.8550 \\
1986 & 10,931 & 40,306 & 7,443 & 4.1884 \\
1987 & 11,931 & 48,473 & 9,136 & 4.4374 \\
1988 & 13,887 & 60,805 & 11,143 & 4.7019 \\
& 16,979 & 76,875 & 13,175 & 4.9375 \\
\hline
\end{tabular}

TABLE AS

Indexes of State and Collective Industrial Output, Capital, and Labor Serits, Independent Accounting Units, Jiangsu Province, 1980-88

\begin{tabular}{lcccc}
\hline & Net Output & Gross Output & Capital & Labor \\
\hline State industry: & 100 & & & \\
1980 & 104 & 100 & 100 & 100 \\
1981 & 107 & 105 & 96 & 105 \\
1982 & 115 & 113 & 113 & 109 \\
1983 & 130 & 124 & 121 & 112 \\
1984 & 147 & 134 & 128 & 113 \\
1985 & 154 & 154 & 139 & 117 \\
1986 & 166 & 170 & 154 & 122 \\
1987 & 187 & 192 & 191 & 126 \\
1988 & & 216 & 209 & 132 \\
Collective industry: & 100 & 100 & 100 & 100 \\
1980 & 108 & 112 & 116 & 106 \\
1981 & 114 & 121 & 133 & 113 \\
1982 & 131 & 141 & 143 & 123 \\
1983 & 164 & 190 & 157 & 134 \\
1984 & 222 & 259 & 198 & 145 \\
1985 & 242 & 312 & 243 & 154 \\
1986 & 282 & 391 & 296 & 163 \\
1987 & 344 & 494 & 350 & 171 \\
1988 & & & & \\
\hline
\end{tabular}

SOURCE.-Table A4. 


\section{Notes}

* I would like to thank Roy Bahl and the members of the Policy Research Program at Georgia State University for their support when I worked on this article while on leave from Carleton College. The Committee on Scholarly Communication with the People's Republic of China supported the initial data collection, and the PICAS Program at the University of Michigan supported further research. I am grateful to Tom Lyons, Eva Paus, Tom Rawski, and Jean Tesche for their valuable suggestions.

1. See, e.g., Bela Balassa, "Exports, Policy Choices, and Economic Growth in Developing Countries after the 1973 Oil Shock," Journal of Devel. opment Economics 18, no. 1 (May-June 1985): 23-35.

2. See, e.g., Devid Evans and Parvin Alizadeh, "Trade, Industrialization, and the Visible Hand," Journal of Development Studies 21, no. 1 (October 1984): 22-46; and Woo S. Jung and Peyton J. Marshall, "Exports, Growth and Causality in Developing Countries," Journal of Development Economics 18, no. 1 (May-June 1985): 1-12.

3. Thomas P. Lyons, Economic Integration and Planning in Maoist China (New York: Columbia University Press, 1987); Christine P. W. Wong, "Ownership and Control in Chinese Industry: The Maoist Legacy and Prospects for the 1980s," in U.S. Congress, Joint Economic Committee, China's Economy Looks toward the Year 2000 (Washington, D.C.: Government Printing Office, 1986), 1:571-603.

4. Gary $H$. Jefferson estimated efficiency differentials due to variations in scale, product mix, level of governmental supervision, and investment for China's iron and steel industry using cross-sectional enterprise data ("China's Iron and Steel Industry: Sources of Enterprise Efficiency and the Impact of Reform," Journal of Development Economics 33, no. 2 [1990]: 329-55).

5. Haitao Yue, "Export-oriented Economy in South Jiangsu," Beijing Review 31 (September 5-11, 1988): 21.

6. Richard Pomfret, "Jiangsu's New Wave in Foreign Investment," China Business Review 16 (November-December 1989): 12.

7. Gene Tidrick, "Productivity Growth and Technological Change in Chinese Industry," World Bank Staff Working Paper no. 761 (World Bank, Washington, D.C., 1986), p. 4.

8. Nicholas R. Lardy, "Technical Change and Economic Reform in China: A Tale of Two Sectors" (University of Washington, Jackson School of International Studies, Seattle, typescript), pp. 2-4.

9. Kuan Chen, Hongchang Wang, Yuxin Zheng, Gary H. Jefferson, and Thomas G. Rawski, "Productivity Change in Chinese Industry: 1953-1985," Journal of Comparative Economics 12 (1988): 582-86.

10. Shu-yun Ma, "Recent Changes in China's Pure Trade Theory," China Quarterly, no. 106 (June 1986), pp. 291-305.

11. Penelope B. Prime, "The Spatial Implications of China's Economic Reforms, 1978 to 1988," in The Uneven Landscape: Geographic Studies in Post-Reform China, ed. Gregory Veeck, Geoscience and Man, vol. 30 (Baton Rouge: Geoscience Publications, Louisiana State University, 1991).

12. Clifton W. Pannell, "Economic Reforms and Readjustment in the People's Republic of China and Some Geographic Consequences,' Studies in Comparative International Development 22, no. 4 (1987-88): 55-61; Thomas P. Lyons, "Concentration and Specialization in Chinese Agriculture, 19791985," Journal of Developing Areas 22 (1988): 437-56.

13. Thomas P. Lyons, "Spatial Aspects of Development in China: The Motor Vehicle Industry, 1956-1985," International Regional Science Review 11 , no. 1 (1987): 75-96. 
14. See, e.g., Nicholas D. Kristof, "Beijing Authority Being Challengyed by Local Powers," New York Times (December 11, 1988).

15. David Faure, "The Rural Economy of Kiangsu Province, 18701911," Journal of the Institute of Chinese Studies of the Chinese University of Hong Kong 9, no. 2 (1978): 365-471, and "The Plight of the Farmers: A Study of the Rural Economy of Jiangnan and the Pearl River Delta, 18701937," Modern China 11 (January 1985): 3-37.

16. Penelope B. Prime, "Central-Provincial Investment and Finance: The Cultural Revolution and Its Legacy in Jiangsu Province," in New Perspectives on the Cultural Revolution, ed. William Joseph, Christine Wong, and David Zweig (Cambridge, Mass.: Harvard University Press, 1991), table 3 and fig. 1.

17. Zhongguo tongji nianjian, 1989 (China's statistical yearbook) (Beijing: Zhongguo Tongji Chubanshe, 1989), p. 269.

18. Jiangsu jingji nianjian, 1989 (Jiangsu's economic yearbook) (Nanjing: Nanjing Daxue Chubanshe, 1989), sec. 3, pp. 45-46.

19. Ibid., sec. 3 , p. 79.

20. Ibid., sec. 3, p. 70.

21. Saul Pleeter, ed., Economic Impact Analysis: Methodology and Applications (Boston: M. Nijhoff, 1980), pp. 34-35.

22. In a market economy, a location quotient is an indicator of regional balance between demand and supply. For example, a quotient less than 1 implies that there is excess demand for that good in the region measured, and therefore that region would be likely to import the good. This interpretation assumes production functions, income elasticities, and tastes are the same across regions. These assumptions and interpretations are not necessary for the application here, which is simply to compare one region's production structure with the rest of the country.

23. Jiangsu's 11 regions are designated by the province's major cities and their surrounding counties. This organization of counties grouped with cities replaced the prefectures in 1983. The 11 regions are Nanjing, Wuxi, Changzhou, Nantong, Suzhou, Xuzhou, Yangzhou, Lianyungang, Zhenjiang, Yancheng, and Huaiyin.

24. Comparable data for years before 1978 were not available.

25. Christine P. W. Wong, "Interpreting Rural Industrial Growth in the Post-Mao Period," Modern China 14 (1988): 3-30.

26. Per capita industrial output would be a better measure. Population figures by region, however, were available only for 1983 and 1988. Using 1984 industrial output with 1983 population gave a coefficient of .70 . The coefficient for per capita industrial output for 1988 was .74 . Therefore, based on the information that is available, the per capita trend was consistent with the trends in table 2.

27. In contrast, the coefficient for agriculture declined with the new definition from .49 in 1983 to .47 in 1985 , and increased with the old definition from .40 to .44 . These trends are consistent with the interpretation that variation in village industry by region is an important component of the coefficients for industry with the new definition.

28. The approach in this article is based on that by Henry J. Bruton in "Productivity Growth in Latin America," American Economic Review 57 (December 1967): 1099-1116. See also Anne O. Krueger and Baran Tuncer, "Estimating Total Factor Productivity Growth in a Developing Country," World Bank Staff Working Paper no. 422 (World Bank, Washington, D.C., 1980), pp. 17-19.

29. Although inappropriate for specific enterprises or industries (Jefferson, "China's Iron and Steel Industry" [n. 4 above]), a Cobb-Douglas produc- 
tion function was chosen to represent the provincial industrial sector overall. Recent estimates for China support using a Cobb-Douglas form since the hypothesis that the production function was Cobb-Douglas could not be rejected (Chen, Wang, et al. [n. 9 above], pp. 580-81; Gary H. Jefferson, "Potential Sources of Productivity Growth within Chinese Industry," World Development 17, no. 1 [1989]: 46, n. 6).

30. Jefferson, "Potential Sources of Productivity Growth within Chinese Industry," p. 48.

31. Another study's estimate for rural collectives (specifically township, village, and private enterprises) resulted in a capital-output elasticity of .75 , and a labor-output elasticity of .25 , which was close to Jefferson's results (William A. Byrd, "Rural Industrialization and Ownership in China" [paper presented at the American Economic Association annual meetings, New York, December 28-30, 1988], p. 19).

32. The new estimate for the capital-output elasticity, and the estimate used here, was .724.

33. The capital-output elasticity for this data series was .643.

34. Gary Jefferson, Thomas G. Rawski, and Yuxin Zheng, "Growth, Efficiency, and Convergence in China's State and Collective Industry," Economic Development and Cultural Change 40 (1992): 239-66.

35. Robert Michael Field, "China: The Changing Structure of Industry," in U.S. Congress, Joint Economic Committee (n. 3 above), 1:509-11.

36. Jiangsu jingji nianjian, 1989 (n. 18 above), sec. 3, p. 44; Penelope B. Prime, "The Impact of Self-Sufficiency on Regional Industrial Growth and Productivity in Post-1949 China: The Case of Jiangsu Province" (Ph.D. diss., University of Michigan, 1987), p. 111, table 4.17.

37. Kuan Chen, Gary H. Jefferson, Thomas G. Rawski, Hongchang Wang, and Yuxin Zheng, "New Estimates of Fixed Investment and Capital Stock for Chinese Industry," China Quarterly, no. 114 (1988), pp. 243-66.

38. Jefferson, Rawski, and Zheng, p. 36.

39. Chen, Jefferson, et al., table A3, p. 261. 
Copyright of Economic Development \& Cultural Change is the property of University of Chicago Press and its content may not be copied or emailed to multiple sites or posted to a listserv without the copyright holder's express written permission. However, users may print, download, or email articles for individual use. 